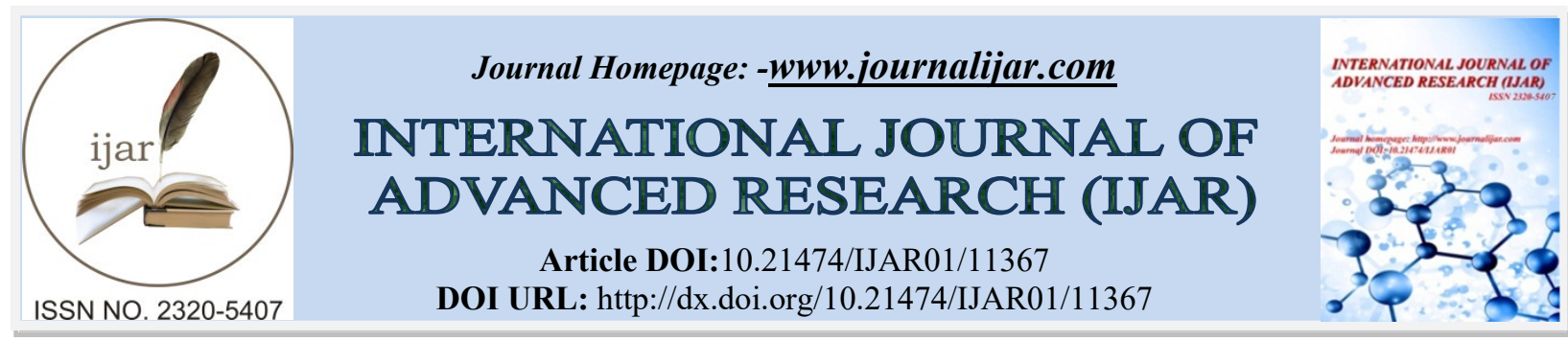

RESEARCH ARTICLE

\title{
BLACK MONEY AND TAX AMNESTY: THE EFFECTIVENESS OF TAX AMNESTY SCHEMES IN HANDLING THE MENACE OF UNACCOUNTED INCOME IN INDIA
}

\author{
Ayushi Kushwaha
}

\section{Manuscript Info}

Manuscript History

Received: 20 May 2020

Final Accepted: 24 June 2020

Published: July 2020

\begin{abstract}
The question of whether we can entirely eliminate black money in existence is challenging. However, one can argue that we can endeavour to bring much of it within the system. One of the many methods that have been suggested for quite some time is tax amnesty schemes. In India, tax amnesty schemes have been in existence for a long time, and though they have been refashioned under different names, they have become a preferable method of encouraging tax evaders to pay their dues in consideration of certain relaxations.Tax Amnesty schemes are aimed at drawing out tax evaders and bringing the unaccounted money into state treasury. Despite the noble objective behind their operation, many argue that these schemes do more harm than good. However, in order to determine the efficacy of these arguments it becomes imperative to analyse the history of these schemes in India and how they have fared in reality. This article attempts to cover the history of tax amnesty schemes in India and evaluate them on a number of factors, particularly moral and economic grounds, so as to determine whether they have been effective in handling black money in the country.
\end{abstract}

Copy Right, IJAR, 2020,. All rights reserved.

\section{Introduction:-}

An Overview of Black Money in India:

With the passage of time, the public discourse on the rising menace of black money has compelled State machineries to legislate on new laws and amend existing ones to tackle this never-ending problem which has come to affect the society at large. Black money has become a powerful tool in the hands of the Opposition parties and civil societies to strengthen their onslaught on the credibility of the incumbent government. But, there is more to the dynamics of black money than just the inadequate or poorly implemented governmental policies. The very nature of Black Money is highly disputed and cannot be understood from the standpoint of a layman. As of now, there is no exhaustive definition of black money and there shall never be. In fact, and quite contrary to what is understood in common parlance, there is manifestation of multi-faceted "social, economic and political factors" that have a huge impact on the characterization of black money and, ultimately, institutional governance and public policy.

Black money is generally understood to be unaccounted money obtained through illegitimate or legitimate means. Money so obtained may have been accumulated by means of activities which are punishable under the legal framework of a country, such as smuggling; or money has accumulated due to failure to make payment due to the State such as evasion of taxes and non-compliance with statutory requirements such as industrial laws. However, there is no definite way to define black money by enumerating specific elements of the same. 
The causes of black money, as noted before, are multi-faceted, and involve more than just stashing away money from the eyes of the law. Its causes concern the overall taxation structure of the State, regulation on economic activities, politics, influence of public morality, deteriorating economic health of a State, governmental expenditure, and others. These only broadly define the underlying causes of the generation of black money, and there exists a deeper and more complex web of specific causal factors which directly contribute to the difficulty in the detection of black money.

A number of reports has studied the web of black money across the globe and noted a steady increase in black money in India. In 2010, the World Bank published a report on "Shadow Economies All over the World"which estimated that "shadow economies" account for 31\% of the GDP of around 162 countries in the year 2007. Of this estimate, Indian shadow economy stands at $20.7 \%$ against the world average. Another study, conducted by Business Standard in the year 2013, estimated black money at 30\% of the GDP, which should be around Rs. 28 lakh crore. According to RBI Handbook on Statistics of Indian Economy 2015-16, currency worth Rs.16.42 lakh crore was estimated to be in circulation by late March 2016.

The numbers are huge, but they could be even bigger. The reasons behind such a bulk of black money remaining undetected are, of course, many, but one of the strongest ones is the ability of people to exploit gaps in the regulatory regime of the country.For example, demonetization was a bold move from Indian government which is grappling with increasing incidents of tax evasion and corruption. It was aimed at curbing this menace, by demonetizing Rs. 500 and Rs. 1000 currency notes, as a result of which people would have to deposit these notes in banks to get the newly released Rs. 2000 currency notes. The goal was to enable the tax authorities to investigate into unusual deposits and help in detecting black money. However, the Reserve Bank of India (RBI) reported in the year 2018 that $99.30 \%$ of the demonetized currency was back in the system, indicating that the policy had been materially bypassed by cleverer minds.

Herculean the task it may be, Indian government cannot sit back and watch its citizens mint money in black, while it suffers from a severe crunch of resources in the matters of governance and public welfare. Lately, there have been a number of steps taken to identify unaccounted money and its holders. For example, an agreement was arrived at between India and Switzerland for an "automatic exchange of information" on money stashed in Swiss Banks from 2019. Similarly, there has been a series of other steps taken by the State to contain this menace.

One of the most commonly known means to tackle black money is to encourage taxpayers to pay up their arrears in consideration of reduced or no penalty. This is usually achieved through tax amnesty schemes, which as the name suggests, extend relaxation or waiver to defaulters of tax payments provided certain conditions are met. These schemes, despite being quite common, are often marred by controversies. In India, as well, where these schemes have been rolled out since a long time have met with mixed feedback, though the State continues to invest its faith in their workability time and again. However, tax amnesty schemes invite a detailed discussion in order to understand and appreciate their various contours and relevance in the society - and to also identify the reasons which have contributed to their mixed successes.

In order to understand the whole concept of tax amnesty schemes, their purposes and their operation in India, we shall have to take a step-wise approach. Thus, the subject at issue has been curated and discussed accordingly.

\section{Tax Amnesty Schemes and India:}

In order to create a healthy taxation environment, it is necessary that citizens disclose their incomes and file necessary returns due on them. But, I would not have written a paper on this unless this task was so regularly done. Income disclosures are disappointing, evidently due to the rising tendency of individuals to avoid disclosing their income. The tax regime has, in its arsenal, enough coercive tools to make defaulters pay up, but it understands the ability of 'reinforcement' and 'incentives' to induce citizens into paying their taxes more readily. Hence, amnesty schemes as alternatives have gained traction to secure voluntary compliance.

Tax Amnesty Schemes are, essentially, schemes that encourage citizens to file returns and pay the taxes which they had failed to pay in the past so that they can start afresh without any liability in the current taxation period. However, to incentivize citizens into undertaking such a step, States extend offers such as reduced penalty amounting to $45 \%$ of the income so disclosed. In addition, the taxing authority often assures to refrain from prosecuting the discloser. It is, however, to be noted that these schemes run for a short period of time within which a 
person can avail benefits. In common parlance, the term "tax amnesty schemes" is often used synonymously with "Voluntary Disclosure Scheme".

The introduction of these schemes is not a post-independence phenomenon, as one of the earliest such schemes was rolled out in the year 1946 in which certain high denomination currency notes were demonetized to contain the underground economy which had emerged by the end of World War II. India, post-independence, was involved in the roll-up of a number of repeated tax amnesty schemes, starting from 1951 to 2020.

The 1951 Tyagi Scheme, a Voluntary Disclosure Scheme, was launched that offered very much along the lines of contemporary tax amnesty schemes such as reduced penalty and no prosecution; however, it failed owing to lack of confidence in the minds of people. Due to its failure, the State did not introduce any more tax amnesty schemes until more than a decade later during one of the most troubled times in Indian political and military history.

In the year 1965, against an acute shortage of money on account of the Chinese invasion, the "Sixty-Forty Scheme" was introduced that stipulated a tax rate of $60 \%$ on the disclosed income in consideration of protection from prosecution or any other penalty. Along with these incentives, citizens were promised confidentiality. Despite these incentives, the declaration of unaccounted income was unimpressive due to the high tax rate imposed on such income. The failure of the "Sixty-Forty Scheme" compelled the government to roll out another scheme in the same year, famously called the "Black Scheme", that allowed citizens to pay $60 \%$ tax on the disclosed income accumulated in various years taken together as a single unit. The amount of income disclosed was relatively high, but the tax collected was pegged at dismal Rs. 20 lacs as many disclosures were made under heads with low tax rates such as spouse income. These two schemes was later followed by another scheme introduced under Taxation Laws (Amendment \& Miscellaneous Provisions) Act 1965 to exempt the disclosed income derived from investments made in National Defence Gold Bonds. Overall, the 1965 schemes could not fetch as much as they were expected - in fact, the implementation of these schemes exposed various institutional problems with which their operation was mired and without whose resolution their efficacious application would not be possible.

Another Voluntary Disclosure Scheme was launched in 1975 vide the Voluntary Disclosure of Income and Wealth Ordinance 1975, which was later replaced by a namesake Act in 1976. In this scheme, there were different tax slabs for different individuals. For example, companies were subject to $60 \%$ tax, but others were subject to varied tax slabs. This scheme is considered to be a fair success, as the tax collection was close to Rs. 241 crores. In another 10 years, a set of Amnesty circulars were issued to enable the disclosure of unaccounted incomes and are said to have generated disclosures close to Rs. 700 crores.

Of all the schemes to have been rolled out in the $20^{\text {th }}$ century, the 1997 scheme invited unprecedented large-scale attention, as it had been campaigned as a "golden chance" for citizens to come out in the open and clean up their past dues. It, essentially, enabled citizens to disclose unaccounted income stashed within or outside India accumulated in any year. The tax to be paid on any such disclosed income was fixed at the rate of $35 \%$ for companies and firms, and 30\% for others. The incentives offered under this scheme were, inter alia, exemption from payment of any penalty or interests and protection from any prosecutorial proceedings against the discloser under Wealth Tax Act, the Companies Act, the Income tax Act, and the Foreign Exchange regulations. Moreover, the discloser was promised confidentiality with respect to disclosures made. The government hailed this scheme as a success based on the figures made available to the public. Under the said disclosure scheme, 475,477 declarations valued at Rs. 33,697 crore and tax collection valued at Rs. 9,729 crore were secured However, in reality, the implementation of the scheme suffered several loopholes which were furthered by supplementary notifications, circulars, and clarifications.

A CAG Audit Report concluded that these supplementary notifications, etc were found to be inconsistent with the Financial Act 1997, allowing opportunities to dishonest citizens to take undue advantage of the gaps in the implementation of the schemes. Many who declared under this scheme were mandated to pay tax within three months from the date of filing a declaration. However, many declarants defaulted in the payment of taxes within the specified period who, as a consequence of such failure, should have ordinarily been subjected to the normal provisions of the Income Tax Act 1961. The Report found that no such action under the purview of the provisions of the Act 1961 was taken. There was a lack of any oversight system to keep a track on whether the declarants under this scheme continued to file their returns in the following years. 
There were stark discrepancies in the issuance of certificates under this scheme. As per Section 68(2) of the Finance Act 1997, the Commissioner of Income Tax was authorized to issue to the declarant a certificate following the disclosure of income and payment of taxes. However, it was found that many certificates were issued in cases wherein taxes had not been paid following declarations. Moreover, inadequate actions were taken by relevant authorities, and wherever any action was taken, the levy of interest was not adequate.

There were instances of "under-valuation of jewelry and bullion" which contributed to the dwindling generation of money from disclosures. There were a substantial number of persons, who were not eligible to declare income and file returns under this scheme and who had received certificates. What was sorrier than this was the fact that there was nothing on record which could indicate that the Income Tax Department took any action in this regard.

Numerous instances of approved multiple declarations were detected. Under this scheme, the first income declaration was valid only upon payment of tax, and any subsequent declarations were not accepted under it. However, many such declarations had been approved by the Income Tax Department.

Expectedly, there was outrage against the way the scheme had been implemented. The outrage was fanned when the Kar Vivad Samadhan Scheme was launched in 1998 vide the Finance Act 1998 which led to a case in the Supreme Court. The case on point is All India Federation of Tax Practitioners vs. Union of India \& Ors in which the Petitioner, a registered body whose stated object was to safeguard the interests of taxpayers and ensure just administration of direct tax regime, questioned the constitutionality of the said scheme. The Bombay High Court's ruling — which was also agreeable to the Supreme Court — struck down the provision to Section 93 of the Finance Act 1998 as being an infringement on Article 14 of the Constitution and refrained from interpreting 'arrears' narrowly. The Supreme Court noted that the introduction of such schemes allows tax evaders to get away from prosecution upon payment of a reduced penalty as a result of which honest taxpayers feel discouraged.The thengovernment submitted that it would refrain from introducing any such schemes anymore. However, a decade later, the NDA government at the helm would rebrand these schemes and introduce them amid much excitement and publicity.

In the year 2016, the Income Declaration Scheme was launched vide the Finance Act 2016 to provide a window to those persons who have defaulted in the payment of full taxes in any of the past assessment years prior to the 201718 assessment year to come forward and disclose such income. The scope of the declaration comprised any undisclosed income and investment made in any asset which represented the undisclosed income. Such persons were required to pay a penalty amounting to $45 \%$ of the undisclosed incomeof which $7.5 \%$ surcharge by the name Krishi Kalayan Surcharge was leveled, giving a social purpose to the scheme. The duration of the scheme was June 1, 2016-September 30, 2016.

The benefits under this scheme included the non-imposition of wealth tax on the disclosed assets, exemption from an enquiry under the Wealth Tax Act 1957 and the Income Tax Act 1961 and immunity from claims based on the Benami Transactions (Prohibition) Act 1888. However, failure to declare within the stipulated period would result in non-accrual of these benefits and invite repercussion under the ordinary provisions of the Income Tax Act 1961. A certain class of persons could not avail this scheme such as persons whose income so disclosed was covered within the ambit of the Black Money Act 2015 or who were specifically debarred under a notice issued as per the Income Tax Act 1961.

In the same year, the Union Government rolled out another income disclosure scheme called the Pradhan Mantri Garib Kalyan Yojana (PMGKY), vide the Taxations Laws (Second Amendment) Act 2016 for a period from December 17, 2016 to March 31, 2017. The scheme required the declarant to make a payment of $30 \%$ tax, 33\% cess for the Pradhan Mantri Garib Kalyan, and 10\% penalty. There was a mandatory requirement to make a deposit of an amount equivalent to $25 \%$ of the disclosed income in the Pradhan Mantri Garib Kalyan Deposit Scheme 2016, which would not accrue any interest and would lock the deposits for 4 years. There would, also, be no protection from any penal laws specified under Section 199-O of this scheme. The scheme is said to have been introduced to ensure the smooth operation of welfare schemes running throughout the country and the money generated thereunder was to be used in the development of projects in areas concerning infrastructure, housing, livelihood, and health.

The response to the 2016 disclosure scheme was mixed, though it managed to secure declarations amounting to Rs. 65,250 crore which would fetch Rs. 29,400 crores in taxes. In contrast to the year 1997 in which the disclosed 
income amounted to $1.9 \%$ of the Gross Domestic Product (GDP), the 2016 scheme managed to secure disclosures which amounted to $0.45 \%$ of the GDP. Moreover, the tax collected was pegged at $0.6 \%$ in 1997 whereas at $0.2 \%$ in 2016.

The latest scheme which had attracted the attention of the media is called Vivad se Vishwas Scheme whose purpose is to close in the gap that has historically existed between the taxpayers and the government with respect to taxrelated dispute settlement. Records show that the number of income tax disputes before the Appellate Tax Authorities is quickly inching towards the 500,000 mark. It was against this backdrop that the Finance Minister had introduced the scheme in the Union Budget 2020, proposing the Direct tax Vivad se Vishwas Bill 2020 that ultimately became an Act in the following month.

The key giveaway of this scheme is to encourage taxpayers to resolve their disputes as per the law in consideration of a set of reliefs sanctioned thereunder. Despite being hailed as an essentially dispute resolution scheme, it does have certain features of amnesty schemes. Under the scheme, taxpayers would be delivered a final settlement of their tax-related dispute along with a waiver of penalty and interest provided the said scheme was availed prior to $31^{\text {st }}$ March 2020. Following the stipulated deadline, $10 \%$ of the contentious amount would have to be paid by the taxpayer. It is to be noted that the deadline has been extended considering the ongoing pandemic, and taxpayers can avail this scheme until $31^{\text {st }}$ December 2020.

Whether or not the scheme is a success will depend on a large number of factors. One factor, of utmost contemporary relevance, is the impact of the pandemic. COVID-19 has reached unpredictable scales and severely impacted the economy of the country. With less money coming in during the pandemic, taxpayers, particularly, businesses are largely cash-strapped and may not look kindly at the scheme and instead resort to traditional dispute settlement mechanisms to avoid channeling a chunk of their money in a go. However, it is premature to comment on the efficacy of the scheme at this point of time.

\section{Tax amnesty schemes: a success story?}

Tax evasion is a menace that continues to grow stronger and uglier with time, causing honest citizens to question the abilities of the government to bring back money into the system and utilize it in projects strengthening governance and developing welfare projects. We have already discussed the staggering statistics on black money, and that they may be not necessarily accurate due to the varying nature of black money and the rise in evasive techniques. Many governments across the world consider tax amnesty schemes or voluntary disclosure schemes good alternatives to ordinary tax regulations. However, the ground realities may be different from what are understood to be. The author has put forth observations under three heads, which concern primarily with moral, economic and institutional factors.

\section{The 'moral' principle of redemption:}

A primary argument against the introduction of such schemes is that they discourage honest taxpayers. As we already know, tax amnesty scheme is called so because it offers a certain degree of relief to otherwise offenders under Income Tax Act 1961 while honest tax payers end up paying regular taxes. This was made evident in the Wanchoo Committee Report, which studied the first three amnesty schemes until 1971, and observed that such disclosure schemes should be regarded as "extraordinary" steps and should be resorted to only at times when there is a "national crisis." Frequent reliance on these schemes during ordinary times would "shake the confidence of the honest taxpayers" and may encourage these persons to also engage in tax evasive techniques. The committee went on to state that the policy of tax amnesty schemes will produce counterintuitive effects because frequent implementation may have discouraging effect causing a reduction in the compliance rate.

With respect to the 1975 scheme, the Shankar Archarya Committee highlighted the poor implementation of and oversight framework envisaged in the scheme. While the scheme was a great improvement on previous tax amnesty schemes, it could not manage to perform as good as it was expected. In this scheme, there were different tax slabs which were exploited by dishonest taxpayers who wanted to avail benefits of the scheme. The scheme witnessed large-scale declarations in the names of lenders, women, and children which perpetrated further tax evasion. The Committee noted that there are no long-term benefits of such schemes, and quite opposite to what is imagined, the scheme gives a window to tax evaders to clear their names on paper and the same time, continue hoarding money. This position has been accepted in the Tax Administration Reforms Commission (TARC) report as well which notes 
that these amnesty schemes motivate tax payers to wait out until such schemes are announced so that they can take advantage of the underlying benefits.

\section{Angles to the Perspectives of the Holders of the Undisclosed Income:}

The aforesaid discussion brings us to a juncture where we should consider the perspective of holders of undisclosed incomes. We should, first, understand why persons do not come out to reap benefits under the scheme. The answer to this question lies in the fact that once you disclose your income you will have to disclose your credentials to the Income Tax Department, causing them to remain under the Department's scanner perpetually. Those with a lot of money stashed unaccounted would not be willing to disclose their income to the department and voluntarily invite the scrutiny of one of the most dreaded institutions in the country.

The underlying principle of these schemes is to give a chance to dishonest tax payers to mend their ways and tune their tax-related activities in consonance with the tax regime. However, in practicality, taxpayers think differently and do not necessarily consider this chance as an opportunity to redefine their self. Most of the time, persons decide whether or not to 'redefine' their self on paper only when the concessional tax rates are good enough for them to avoid shelling out too much in penalties. They will evaluate whether the disclosure can give them higher returns or there is a greater risk that they will be put to larger scrutiny upon disclosure. A 1998 study on the efficacy of tax amnesty schemes shows that the 1975 scheme was relatively successful because it was introduced in the backdrop of Emergency which would have otherwise attracted stringent application of Income Tax laws. Hence, the 'moral' principle that forms the essence of these schemes does not play out as much as 'economic' principles-it is more a matter of what will cost less.

\section{Poor Oversight Mechanisms}

Lack of robust institutional mechanisms plays a key role in motivating persons from not disclosing their income. Almost every amnesty scheme stipulates that failure to declare income within a particular period of time will invite prosecution under ordinary Income Tax laws. But, the ground reality speaks a different story. The prosecution rate in tax cases is quite disappointing. This could be very well illustrated from the findings of the CAG Audit Report on the 1997 scheme that highlighted that there were recurring instances of the failure of Income Tax department to take actions against people involved in blatant irregularities, and that the department was not aware of the statuses of many assesses with respect to, for example, tax payment, number of declarations, etc.

\section{Conclusion:-}

The consequences of black money are understood to be severe on the governance of the nation. Black money and its impact permeates through social, economic and political spheres, and there seems to be no panacea to eradicate it completely. It can always be curbed through measures which, for quite a chunk of time, have been punitive in nature. However, in the past few decades, countries have started introducing tax amnesty schemes, contemplating on a possibility of successfully incentivizing persons to pay their dues to the State.

India has had her own set of tax amnesty schemes whose success rates have not been quite laudable. The outcomes of such schemes have largely been unimpressive, though people have come out and declared their incomes. These schemes directly affect the morale of honest tax payers, tickle the minds of holders of undisclosed incomes to only declare income (wholly or partly) when good concessional rates are available under these schemes, and are greatly affected by the lingering institutional lacunae. Thus, a tax amnesty scheme may be, in principle, an attempt to allow room to defaulters to redeem themselves and bring back money to State coffers; however, the real-time application of these schemes have largely produced counterintuitive effects.

\section{References: Statutes, Bills, Rules, etc}

The Finance Act, 1997

The Taxations Laws (Second Amendment) Act 2016

Pradhan Mantri Garib Kalyan Deposit Scheme 2016 


\section{Reports and studies}

'A STUDY ON WIDENING OF TAX BASE AND TACKLING BLACK MONEY' (FICCI, 2015) $<$ http://ficci.in/spdocument/20548/STUDY-ON-WIDENING-OF-TAX-BASE-AND-TACKLING-BLACK-

MONEY.pdf $>$ accessed 22 July 2020.

'Underlying Causes Of The Black Economy: Qualitative Review Of The Principal Factors' (National Institute Of Public Finance And Policy) <https://www.nipfp.org.in/media/pdf/books/BK_14/Chapters/9. Underlying Caused Of The Black Economy.pdf $>$ accessed 22 July 2020.

Report No.12 Of 2005 (Direct Taxes)' (Comptroller and Auditor General of India, 2005) $<$ https://cag.gov.in/sites/default/files/old_reports/union/union_compliance/2004_2005/Direct_Taxes/Report_No_12/ chapter6.pdf> accessed 22 July 2020.

'APPENDIX 'B': SOME KEY CASE STUDIES FROM AUDIT REPORTS' (Comptroller and Auditor General of India $)<$ https://cag.gov.in/sites/default/files/footer_pdf/appendix_b.pdf $>$ accessed 23 July 2020.

\section{Miscellaneous}

Arindam Das-Gupta, Shanto Ghosh and Dilip Mookherjee, 'Tax Administration Reform And Taxpayer Compliance In India' (2004) 11 International Tax and Public Finance $<$ https://link.springer.com/article/10.1023/B:ITAX.0000036692.95048.00>.

Tax Administration Reform In India Spirit, Purpose And Empowerment' (Tax India Online, 2014) $<$ https://taxindiaonline.com/RC2/pdfdocs/TARC3rdReport.pdf $>$ accessed 22 July 2020.

'Vivad Se Vishwas Scheme 2020' (Income Tax Department, 2020) $<$ https://www.incometaxindiaefiling.gov.in/eFiling/Portal/StaticPDF/Vivad_Se_Vishwas_PDF_Links/Brief_DTVS V_Scheme.pdf $>$ accessed 22 July 2020.

'Vivad Se Vishwas' Scheme: CBDT To Review Pendency Of Appeals' (The Economic Times, 2020) $<$ https://economictimes.indiatimes.com/news/economy/policy/vivad-se-vishwas-scheme-cbdt-to-review-pendencyof-appeals/articleshow/74100107.cms?from=mdr> accessed 20 July 2020.

Anand Kalyanaraman, 'This Money Mountain'S No Molehill' (The Hindu Business Line, 2016) $<$ https://www.thehindubusinessline.com/opinion/columns/anand-kalyanaraman/this-money-mountains-nomolehill/article9211912.ece> accessed 22 July 2020.

'EXPLANATORY NOTES ON PROVISIONS OF THE INCOME DECLARATION SCHEME, 2016 AS PROVIDED IN CHAPTER IX OF THE FINANCE ACT, 2016' (Income Tax Department, 2016) $<$ https://www.incometaxindia.gov.in/communications/circular/circular16_2016.pdf > accessed 22 July 2020.

'The Income Declaration Scheme, 2016' (The Institute of Company Secretaries of India) $<$ https://www.icsi.edu/media/webmodules/IncomeDeclarationScheme_2016_PPT.pdf> accessed 22 July 2020.

'CAG Report Finds Gaping Holes In VDIS 1997' (The Hindu Business Line, 2000) $<$ https://www.thehindubusinessline.com/2000/08/26/stories/012664b1.htm> accessed 22 July 2020.

'VOLUNTARY DISCLOSURE OF INCOME SCHEME, 1997' (Income Tax Department) $<$ https://www.incometaxindia.gov.in/Communications/Circular/Others/910110000000000808/dtc44skp.htm> accessed 22 July 2020.

'VOLUNTARY DISCLOSURE OF INCOME \& WEALTH ORDINANCE, 1975' (Income Tax Department) $<$ https://www.incometaxindia.gov.in/Communications/Circular/910110000000001023.htm> accessed 22 July 2020. 
S S Khan, 'Tax Amnesties In India' (Tax India International, 2012) $<$ https://taxindiainternational.com/columnDesc.php?qwer43fcxzt=NzU> accessed 22 July 2020.

Rajiva Ranjan Singh and Anandita Bagchi, 'Demonetisation - A Golden Opportunity For Widening The Taxpayer Base' (Indian Council for Research on International Economic Relations, 2018) $<$ http://icrier.org/pdf/Working_Paper_351.pdf $>$ accessed 22 July 2020.

Shailesh Menon, 'Tax Authorities' Amnesty Schemes Have Failed Miserably' (The Economic Times, 2016) $<$ https://economictimes.indiatimes.com/news/economy/policy/tax-authorities-amnesty-schemes-have-failedmiserably/articleshow/51336088.cms> accessed 22 July 2020.

'Income Declaration Scheme, 2016 | National Portal of India' (National Portal of India, 2016) $<$ https://www.india.gov.in/spotlight/income-declaration-scheme-2016> accessed 22 July 2020.

Steven M. Packer and Barbara A. Ruth, 'State Tax Amnesty And Voluntary Disclosure Programs' (Duane Morris, $2009)<\mathrm{https}: / / \mathrm{www}$.duanemorris.com/articles/state_tax_amnesty_voluntary_disclosure_3433.html $>$ accessed 22 July 2020 .

'RBI | Demonetised Notes: 99.30\% Of Demonetised Money Back In The System, Says RBI Report' (The Economic Times, 2018) <https://economictimes.indiatimes.com/news/economy/finance/after-almost-two-years-of-countingrbi-says-99-3-of-demonetised-notes-returned/articleshow/65589904.cms> accessed 22 July 2020.

'India And Switzerland Sign Bank Information Sharing Deal' (Business-standard, 2018) < https://www.businessstandard.com/article/economy-policy/india-and-switzerland-sign-bank-information-sharing-deal-

116112201166_1.html> accessed 22 July 2020.

'BLACK MONEY' (PRS LEGISLATIVE RESEARCH, 2012) <http://www.prsindia.org/uploads/media/White Paper Black Money/WhitePaper_BackMoney2012.pdf> accessed 22 July 2020.

Shaji Thomas, 'Effects Of Black Money On Indian Economy' (2016) 4 International Journal of Advance Research in Computer Science and Management Studies <http://www.ijarcsms.com/docs/paper/volume4/issue12/V4I120028.pdf $>$ accessed 22 July 2020.

Dr. Yogesh Suri, 'Demonetization - An Opportunity To Curtail Black Money And Promote Digital Payments' (NITI Aayog, 2016) <http://niti.gov.in/writereaddata/files/document_publication/NITI Blog_Curbing black money.pdf> accessed 22 July 2020.

Friedrich Schneider, Andreas Buehn and Claudio E. Montenegro, 'Shadow Economies All Over The World' (World Bank, 2010) <http://documents1.worldbank.org/curated/en/311991468037132740/pdf/WPS5356.pdf > accessed 22 July 2020.

Marie Singer, 'Shadow Economy - Definition And Meaning' (Market Business News) $<$ https://marketbusinessnews.com/financial-glossary/shadow-economy-definition-meaning/> accessed 22 July 2020. 